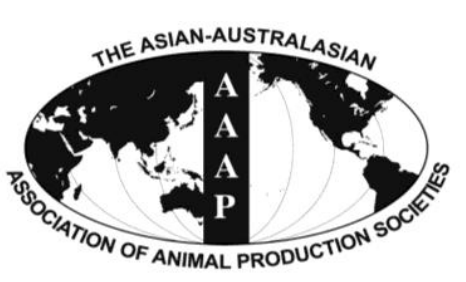

\begin{tabular}{c} 
Open Access \\
Asian Australas. J. Anim. Sci. \\
Vol. 27, No. 4 : 495-502 April 2014 \\
http://dx.doi.org/10.5713/ajas.2013.13522 \\
\hline www.ajas.info \\
pISSN 101 1-2367 elSSN 1976-5517
\end{tabular}

\title{
Effect of Feeding Bacillus subtilis natto on Hindgut Fermentation and Microbiota of Holstein Dairy Cows
}

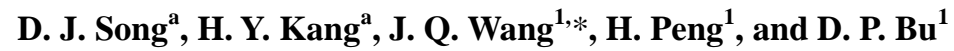 \\ College of Animal Science and Technology, Southwest University, Chongqing 400715, China
}

\begin{abstract}
The effect of Bacillus subtilis natto on hindgut fermentation and microbiota of early lactation Holstein dairy cows was investigated in this study. Thirty-six Holstein dairy cows in early lactation were randomly allocated to three groups: no B. subtilis natto as the control group, B. subtilis natto with $0.5 \times 10^{11} \mathrm{cfu}$ as DMF1 group and B. subtilis natto with $1.0 \times 10^{11}$ cfu as DMF2 group. After 14 days of adaptation period, the formal experiment was started and lasted for 63 days. Fecal samples were collected directly from the rectum of each animal on the morning at the end of eighth week and placed into sterile plastic bags. The $\mathrm{pH}, \mathrm{NH}_{3}-\mathrm{N}$ and VFA concentration were determined and fecal bacteria DNA was extracted and analyzed by DGGE. The results showed that the addition of B. subtilus natto at either treatment level resulted in a decrease in fecal $\mathrm{NH}_{3}-\mathrm{N}$ concentration but had no effect on fecal $\mathrm{pH}$ and VFA. The DGGE profile revealed that B. subtilis natto affected the population of fecal bacteria. The diversity index of Shannon-Wiener in DFM1 decreased significantly compared to the control. Fecal Alistipes sp., Clostridium sp., Roseospira sp., beta proteobacterium were decreased and Bifidobacterium was increased after supplementing with B. subtilis natto. This study demonstrated that B. subtilis natto had a tendency to change fecal microbiota balance. (Key Words: Bacillus subtilis natto, Dairy Cow, Fecal Microbiota, DGGE)
\end{abstract}

\section{INTRODUCTION}

Probiotics are living microbes which administered in adequate amounts confer a health benefit to the host (FAO/WHO, 2001). Some researches showed that probiotics can improve the performance of calves (Meyer et al., 2001; Timmerman et al., 2005), modify intestinal balance (Fuller, 1989) and mitigate calf scours (Wehnes et al., 2009). Probiotics can have several modes of action. These include - restricting colonization of pathogenic microbes on mucosal surfaces by a mechanism of competitive exclusion, stimulating an immune response, facilitating the proliferation of other commensal bacteria and producing antimicrobial substances (La Ragione et al.,

\footnotetext{
* Corresponding Author: Jiaqi Wang. Tel: +86-10-62890458, Fax: +86-10-62897587, E-mail: jqwangcaas@gmail.com

${ }^{1}$ State Key Laboratory of Animal Nutrition, Institute of Animal Science, Chinese Academy Agricultural Sciences, Beijing 100193, China.

${ }^{a}$ These two authors contribute equally to this work.

Submitted Aug. 20, 2013; Accepted Oct. 29, 2013; Revised Nov. 27, 2013
}

2001; Hong et al., 2005; Leser et al., 2009).

The major probiotic strains are Lactobacillus, Saccharomyces, Bacillus, Streptococcus, and Aspergillus (Tannock, 2001), and so on. Most of the previous research on probiotics were focused on the application of various strains of lactic acid bacteria (Miettinen et al., 1996; Holzapfel et al., 2001). Several Bacillus sp. bacteria, such as Bacillus licheniformis and Bacillus subtilis have gained more attention for their role in controlling infectious diseases, thereby improving productive performance in animals (Holzapfel et al., 2001). Unlike the lactic acid bacteria, Bacillus sp. is not normally found in the gastrointestinal tract. Bacillus sp. exists in an endosymbiotic relationship with their host, being temporarily able to survive and proliferate within gastrointestinal tract (GIT) and finally excreted in the faeces (Hong et al., 2005). Bacillus sp. also provides beneficial effects via one or a number of the modes of action described above (Wehnes et al., 2009). Bacillus sp. have demonstrated effectiveness as probiotics because they have been shown to be capable of inhibiting pathogens, such as Clostridium sp. (Guo et al., 2006), Campylobacter sp. 
(Fritts et al., 2000), Streptococcus sp. (Teo and Tan, 2005), Escherichia coli (Teo and Tan, 2006), Salmonella typhimurium, and Staphylococcus aureus (Sumi et al., 1997). $B$. subtilis natto isolated from the Japanese fermented soybean staple known as 'natto' is a gram-positive sporeforming bacterium and is a subspecies of $B$. subtilis according to the 16S rRNA sequence analysis (Qin et al., 2005). Our prior research suggested that the viable probiotic characteristics of $B$. subtilis natto was beneficial to the immune system of the calf (Sun et al., 2010).

The gastrointestinal tract of healthy animals is colonized by a complex microbiota formed by many different species of microorganism (Frizzo et al., 2008). The microbial balance in the microbiota of the digestive tract is important to promote efficient digestion and maximum nutrient absorption. It can increase the host capacity for excluding pathogen microorganisms and thus, to prevent some diseases at the same time (Walter et al., 2003). The microbial shedding and fermentation parameters of the feces can particularly reflect the true condition of the hindgut (Fox et al., 2007). However, the effects of dietary supplementation with $B$. subtilus natto on hindgut microbiology and microbial population have been rarely investigated. Consequently, this study was designed to assess the effect of $B$. subtilis natto on hindgut microbiota and fermentation of Holstein dairy cows.

\section{MATERIALS AND METHODS}

\section{Cows and diets}

All animals used in this experiment were maintained according to the principles of the Chinese Academy of Agricultural Sciences Animal Care and Use Committee. The study was conducted at the Beijing Dairy Cattle center in Yanqing Conty, Beijing. Thirty-six early lactation Holstein dairy cows were used in this experiment, and the experiment dates were from March 9th to May 3rd, 2010. Cows were fed a typical total mixed ration (TMR) based on China Standard NY/t 34 (2004) and NRC (2001) (Table 1) and pre-weighted rations $(110 \%)$ of TMR was supplied to the cows every meal.

\section{Experimental design}

After two weeks of adaptation feeding, cows were divided into three groups: i) no B. subtilis natto as the control group (CON); ii) cows were fed the TMR diet supplemented with $6 \mathrm{~g} / \mathrm{d}$ B. subtilis natto fermentation product $\left(0.5 \times 10^{11} \mathrm{cfu}\right.$ of $B$. subtilis natto/d) (DFM1); and iii) cows were fed the TMR diet supplemented with $12 \mathrm{~g} / \mathrm{d}$ B. subtilis natto fermentation product $\left(1.0 \times 10^{11}\right.$ cfu of $B$. subtilis natto/d) (DFM2). The TMR was given three times a day at 0700,1400 and 2100 with the B. subtilis natto being added daily in the morning feeding. The solid state
Table 1. Ingredient and chemical composition of the diet (DM basis)

\begin{tabular}{|c|c|}
\hline Item & TMR \\
\hline \multicolumn{2}{|l|}{ Ingredient (\%) } \\
\hline Corn silage & 23.10 \\
\hline Alfalfa hay & 9.20 \\
\hline Chinese wildrye & 8.60 \\
\hline Corn grain & 12.90 \\
\hline Dry distillers grains & 2.60 \\
\hline Soybean meal & 8.80 \\
\hline Soybean dried grain & 3.73 \\
\hline Barley grain & 5.90 \\
\hline Beet pulp & 5.90 \\
\hline Cotton seed meal & 3.93 \\
\hline Soybean curb residue & 5.60 \\
\hline Wheat bran & 2.40 \\
\hline Calcium hydrogen phosphate & 1.32 \\
\hline Rumen protected methionine & 0.06 \\
\hline Fatty powder & 0.85 \\
\hline Limestone & 1.56 \\
\hline Salt & 1.02 \\
\hline Molasses & 0.08 \\
\hline Sodium bicarbonate & 1.81 \\
\hline Magnesium oxide & 0.21 \\
\hline Premix $^{1}$ & 0.43 \\
\hline Total & 100.00 \\
\hline \multicolumn{2}{|l|}{ Chemical composition } \\
\hline $\mathrm{NE}_{\mathrm{L}}^{2}(\mathrm{Mcal} / \mathrm{kg} \mathrm{DM})$ & 1.38 \\
\hline $\mathrm{CP}(\% \mathrm{DM})$ & 17.77 \\
\hline NDF (\% DM) & 43.80 \\
\hline $\mathrm{ADF}(\% \mathrm{DM})$ & 21.83 \\
\hline $\mathrm{Ca}(\% \mathrm{DM})$ & 0.94 \\
\hline $\mathrm{P}(\% \mathrm{DM})$ & 0.41 \\
\hline
\end{tabular}

${ }^{1}$ Contained per kilogram of the premix: vitamin A, 2,000,000 IU; vitamin D, 300,000 IU; vitamin E, 3,000 IU; Cu, 3,500 mg; Fe, 10,000 mg; Zn, 10,000 mg; Mn, 9,000 mg; Mg, 9,800 mg; I, 90 mg; Se, 40 mg; Co, 30 $\mathrm{mg}$

${ }^{2}$ Calculated value (based on China Standard NY /t 34, 2004 and NRC (2001)).

fermentation products were produced by Langfang Dongxin Biological Technology Co., LTD (China) using the prior identified B. subtilis natto from our laboratory. The number of viable B. subtilis natto spores in the product was determined by plate count on LB medium (5\% agar, $0.5 \%$ $\mathrm{NaCl}, 1 \%$ soya peptone, $0.3 \%$ beef extract, $\mathrm{pH}=7.0)$ after heat treatment $\left(80^{\circ} \mathrm{C}\right.$ for $\left.10 \mathrm{~min}\right)$, and approximately $8.3 \times 10^{9}$ spores per gram of solid-state fermentation product were obtained. Animals had free access to fresh water and a plain mineral block during the period of the experiment.

\section{Sample collection and analysis}

Fecal samples were collected directly from the rectum of each animal on the morning at the end of eighth week 
and placed into sterile plastic bags. These bags were kept on ice until the sampling of all animals was completed. The entire process was limited to one hour's duration

Fecal $p H$ : The $\mathrm{pH}$ of fresh feces was determined immediately after defecation by thoroughly mixing $10 \mathrm{~g}$ fresh feces with $20 \mathrm{~mL}$ double-deionized water in $50 \mathrm{~mL}$ tubes and submerging the $\mathrm{pH}$ probe $(370$ model $\mathrm{pH}$ meter, Jenway, UK) in the mixture (Breg et al., 2005). Then $4 \mathrm{ml}$ of the feces suspension was placed into a $10 \mathrm{~mL}$ sterile test tube. $1 \mathrm{~mL} 25 \%$ meta-phosphoric acid was added into $4 \mathrm{~mL}$ of the feces suspension, then mixed well and stored at $-20^{\circ} \mathrm{C}$ for further $\mathrm{NH}_{3}-\mathrm{N}$ and VFA analysis.

Fecal $\mathrm{NH}_{3}-\mathrm{N}$ and VFA: Fecal $\mathrm{NH}_{3}-\mathrm{N}$ was measured according to Bromner and Keeney (1965). Fecal VFA concentrations were determined using gas chromatography (model 6890, Series II; Hewlett Packard Co., Avondale, PA) using a DB-FFAP $(15 \mathrm{~m} \times 0.32 \mathrm{~mm} \times 0.25 \mu \mathrm{m})$ and FID. The samples were run at a split ratio of 50:1 with a programmed temperature gradient $\left(100^{\circ} \mathrm{C}\right.$ initial temperature for $1 \mathrm{~min}$, with a $2^{\circ} \mathrm{C}$ rise per min to $120^{\circ} \mathrm{C}$ and a 10 min final temperature). The temperature of the injector and detector was $250^{\circ} \mathrm{C}$ and $280^{\circ} \mathrm{C}$ respectively. The carrier gas was $\mathrm{N}_{2}$, and column flow rate was $1 \mathrm{~mL} / \mathrm{min}$ (Mohammed et al., 2004).

PCR-DGGE: The fecal DNA of the eight week was extracted by the method of RBB+C (Yu et al., 2004). For DGGE analysis, approximately $200 \mathrm{bp}$ of the fecal total 16S rDNA gene was amplified using primers: 338f (5'ACTCCTACGGGAGGCAGC AG-3') and 533r (5'TTACCGCGGCTGCTGGCAC-3') and with a 40-base GCclamp (CGCCCGCCGCGCGCGGCGGGCGGGGCGGG GGCACGGGGGG) at the 5' terminus of 338f primer. All PCR amplifications were performed in $50 \mu \mathrm{L}$ volumes containing $25 \mu \mathrm{L} 2 \times$ HiFiTaq StarMix (GenStar, USA), $1 \mu \mathrm{L}$ $500 \mathrm{nM}$ each primer, $100 \mathrm{ng}$ DNA template. After prior denaturation at $94^{\circ} \mathrm{C}$ for $4 \mathrm{~min}, 10$ cycles of touchdown PCR were performed $\left(94^{\circ} \mathrm{C}\right.$ for $30 \mathrm{~s}, 61^{\circ} \mathrm{C}$ for $30 \mathrm{~s}$, with a $0.5^{\circ} \mathrm{C}$ per cycle decrement, and $72^{\circ} \mathrm{C}$ for $1 \mathrm{~min}$ ), followed by 25 cycles of PCR $\left(94^{\circ} \mathrm{C}\right.$ for $30 \mathrm{~s}, 56^{\circ} \mathrm{C}$ for $30 \mathrm{~s}$, and $72^{\circ} \mathrm{C}$ for $1 \mathrm{~min}$ ), and a final extension step at $72^{\circ} \mathrm{C}$ for 7 $\min$.

The PCR-DGGE was performed using a DCode Universal Mutation Detection System (Bio-Rad Laboratories, Hercules, CA, USA). Fifteen $\mu \mathrm{L}$ of PCR products were loaded in a $7.5 \%$ polyacrylamide/gel $(37.5: 1)$ in $0.5 \times \mathrm{TAE}(20 \mathrm{mmol} / \mathrm{L}$ Tris- $\mathrm{HCl}, 10 \mathrm{mmol} / \mathrm{L}$ acetic acid, $0.5 \mathrm{mmol} / \mathrm{L}$ EDTA adjusted to $\mathrm{pH} 8.3$ ) buffer. The polyacrylamide gels contained a $40 \%$ of denaturant at the top of the gel grading to a $60 \%$ denaturant at the bottom (100\% denaturants consisting of $40 \%$ [v/v] formamide and $7 \mathrm{M}$ urea). The DGGE gel was run for $16 \mathrm{~h}$ at $60^{\circ} \mathrm{C}$ and $85 \mathrm{~V}$. After electrophoresis, the gels were stained with silver nitrate (Yu et al., 2004).

Sequencing: Putative indicator bands were excised from the gels and DNAs were recovered according to boiling methods (Wang et al., 2006). The 16S rDNA from each band was enriched by PCR using the same primer 338f and 533r without a GC-clamp under the prior PCR process. Purified PCR products were cloned into pMD18-T vector, and transformed into Escherichia coli JM109 competent cells following the manufacturer's instructions (TaKaRa, Japan). Screening the positive clones in the LB solid medium containing X-Gal and ampicillin (Amp), and the sequencing was completed by the BGI Company, Beijing center (Beijing, China). After aligning with sequences from GenBank and RDP, 16S rDNA sequences were blasted individually with the highest similar sequence.

\section{Statistical analysis}

All data were analyzed using the Proc Mixed procedure of the SAS system (version 8.2, SAS Institute Inc., Cary, NC). p-Values $<0.05$ were considered statistically significant, and trends were discussed at $\mathrm{p}<0.1$.

For microbial diversity analysis, after staining, DGGE gels were scanned and analyzed using Quantity-one software (Bio-Rad) and the peak density was calculated. The unweighted pair group method using arithmetic averages (UPGMA) algorithm was used as implemented in the analysis software for the construction of dendrograms. The microbial diversity was analyzed according to Shannon-Wiener index ( $H^{\prime}$ ) (Spellerberg and Fedor, 2003):

$$
\mathrm{H}^{\prime}=-\sum \mathrm{P}_{\mathrm{i}} \log \mathrm{P}_{\mathrm{i}}
$$

$P_{i}=N_{i} / N$, relative intensity in the profile

$\mathrm{N}_{\mathrm{i}}=$ surface of the peak $\mathrm{i}$

$\mathrm{N}=$ sum of the surfaces for all the peak within the profile

\section{RESULTS}

\section{Fecal $\mathrm{pH}, \mathrm{NH}_{3}-\mathrm{N}$ and VFA}

All results are listed in Table 2. There were no treatment effects on fecal $\mathrm{pH}$ during this study. Compared to the Control group, supplementation of B. subtilis natto in the diets led to a significant decrease in total fecal $\mathrm{NH}_{3}-\mathrm{N}$ in DFM1 and DFM2 ( $<<0.10)$. No differences were observed in total fecal VFAs or the proportion of individual VFAs such as: acetate, propionate, butyric, isobutyric, valeric or isovaleric when cows were supplemented with either $0.5 \times 10^{11} \mathrm{cfu}$ of $B$. subtilis natto/d or $1.0 \times 10^{11} \mathrm{cfu}$ of B. subtilis natto/d.

\section{Fecal microbial analysis}

The total fecal DNA, DGGE fingerprint for the eighth 
Table 2. Effects of feeding Bacillus subtilis natto on fecal $\mathrm{pH}, \mathrm{NH}_{3}-\mathrm{N}$, and VFA

\begin{tabular}{|c|c|c|c|c|c|}
\hline \multirow{2}{*}{ Item } & \multicolumn{3}{|c|}{ Treatment $^{1}$} & \multirow{2}{*}{ SEM } & \multirow{2}{*}{ p-value } \\
\hline & $\mathrm{CON}$ & DFM1 & DFM2 & & \\
\hline$\overline{\mathrm{pH}}$ & 6.83 & 6.78 & 6.76 & 0.04 & 0.37 \\
\hline $\mathrm{NH}_{3}-\mathrm{N}(\mathrm{mg} / \mathrm{mL})$ & 13.01 & 10.36 & 10.02 & 0.89 & 0.07 \\
\hline TVFA (mmol/L) & 22.93 & 22.43 & 22.63 & 1.01 & 0.94 \\
\hline Acetate $(\mathrm{mmol} / \mathrm{L})$ & 17.34 & 16.35 & 17.12 & 0.8 & 0.667 \\
\hline Propionate $(\mathrm{mmol} / \mathrm{L})$ & 3.99 & 4.08 & 3.88 & 0.19 & 0.80 \\
\hline Butyric (mmol/L) & 0.90 & 0.91 & 0.91 & 0.07 & 0.99 \\
\hline Valeric (mmol/L) & 0.3213 & 0.2809 & 0.2915 & 0.01 & 0.16 \\
\hline Isobutyric (mmol/L) & 3.99 & 3.96 & 3.88 & 0.21 & 0.94 \\
\hline Isovaleric (mmol/L) & 0.2 & 0.18 & 0.18 & 0.01 & 0.83 \\
\hline
\end{tabular}

${ }^{1} \mathrm{CON}=$ No $B$. subtilis natto DFM1 $=0.5 \times 10^{11} \mathrm{CFU}$ of $B$. subtilis natto/d; DFM2 $=1.0 \times 10^{11} \mathrm{CFU}$ of $B$. subtilis natto/d.

week for both CON and DFM1 is shown in Figure 1(a). Examination of the gel indicated that the position and number of bands were similar in each group. However Bands 1, 2, 4, 5, 6, 7, and 8 were decreased in intensity or disappeared in the same fingerprint of the DFM1 group, while bands 3, 9, and 11 increased in intensity compared with the CON. In addition the band group labeled ' 10 ' was a new band group which was not present in the CON fingerprint. It was also observed that there were numerous color differences in this gel that were implied the difference in density. Dendrograms shown that lanes belonged to the same group: lanes $1,2,3,4,5,6$, and lanes $7,8,9,10,11$, 12 clustered respectively and the similarity of the two groups was about $66 \%$ (Figure 1(b)). Labeled bands were excised and sequenced, the results are shown in Table 3, fecal Alistipes sp., Clostridium sp., Roseospira sp., beta proteobacterium were decreased and Bifidobacterum was increased after supplementing B. subtilis natto. However, some bands were changed such as bands group 1, 2, 3, 7, and 11, that were uncultured bacteria sp.. Even if they were excised from the band groups, the sequence was inconsistent. For example - bands 4, 5, 6, 9, and 10 generated two different results. The Shannon-Wiener index of CON and DFM1 was $3.3476 \pm 0.07$ and $3.0725 \pm 0.08$ respectively, and a significant difference was obtained in our study when supplementing $B$. subtilis natto in the diets at eight week $(\mathrm{p}<0.10)$.

\section{DISCUSSION}

This study investigated the effects of supplementing B. subtilis natto on hindgut fermentation and microbiota through fecal. No obvious changes in fecal $\mathrm{pH}$ were observed, however, a small decline in fecal $\mathrm{pH}$ was previously associated with altered fermentation patterns and microbial ecology in the hindgut (Medina et al., 2002). Similar results were also observed by Qiao et al. (2010). The decrease of fecal $\mathrm{pH}$ in this study may have contributed to the increase of Bifidobacteria in the hindgut of the cows fed B. subtilis natto. It is also possible that the decline of fecal $\mathrm{pH}$ may connect with the decrease of fecal $\mathrm{NH}_{3}-\mathrm{N}$ concentration. In this study - when the B. subtilis natto product was added to the diets - the concentration of total dietary $\mathrm{N}$ did not change. However, the resultant concentration of fecal $\mathrm{NH}_{3}-\mathrm{N}$ was decreased $(\mathrm{p}<0.01)$. Fecal $\mathrm{N}$ contains mainly undigested feed protein and metabolic fecal N (de Boer et al., 2002). Therefore, these results can be explained by assuming that the supplementation of $B$. subtilis natto product enhanced the diet utilization efficiency and reduced the excretion of protein in the feces (Spiehs et al., 2009). Previous research suggested that feeding fermented products of $B$. subtilis to layer hens (Santoso et al., 1999) and broilers (Santoso et al., 1995) reduced $\mathrm{NH}_{3}-\mathrm{N}$ release from excreta significantly, so we would surmise that there is a microbiological component which can reduce urease activity within the fecal microbial population. No difference in fecal VFAs or the concentration of individual VFAs was observed in the treatment groups that were supplemented with $B$. subtilis natto. Similar results were reported in meat goats, but no consistent benefit was noted from supplementing healthy, growing meat goats with probiotic products (Whieley et al., 2009).

The microbial population of the intestine plays an important role in overall animal health, productivity and well-being. Therefore, assessing the diversity of microbial communities (in terms of richness and structure) is a useful indicator as to how animals evolve within their environment (Fromin et al., 2002). In this study we reported the changes in hindgut microflora as measured in the faeces after supplementing B. subtilis natto using DGGE methods. There was a significant difference for the Shannon-Wiener index $\left(\mathrm{H}^{\prime}\right)$ between the CON group and the DFM1 group at the eighth week, suggesting that the microbial population in the rumen of the cows in this study was affected by supplementing $B$. subtilis natto. Studies have demonstrated that probiotics can provide good production responses in various fields of animal production (Fuller, 1989; Hosoi et 


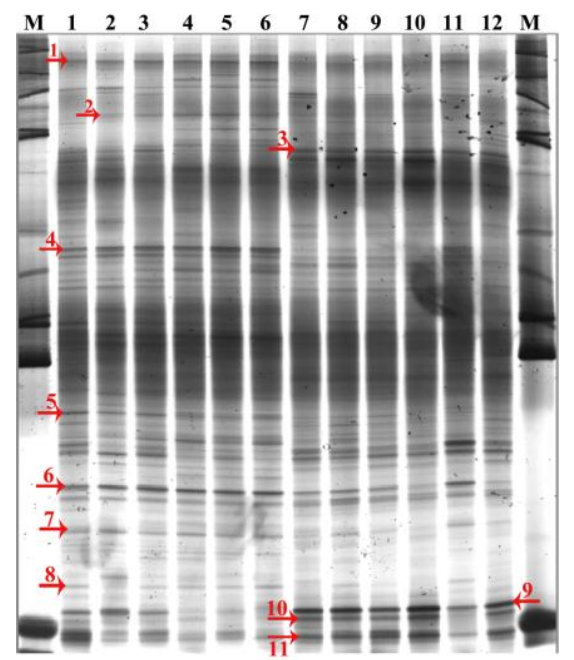

(a)

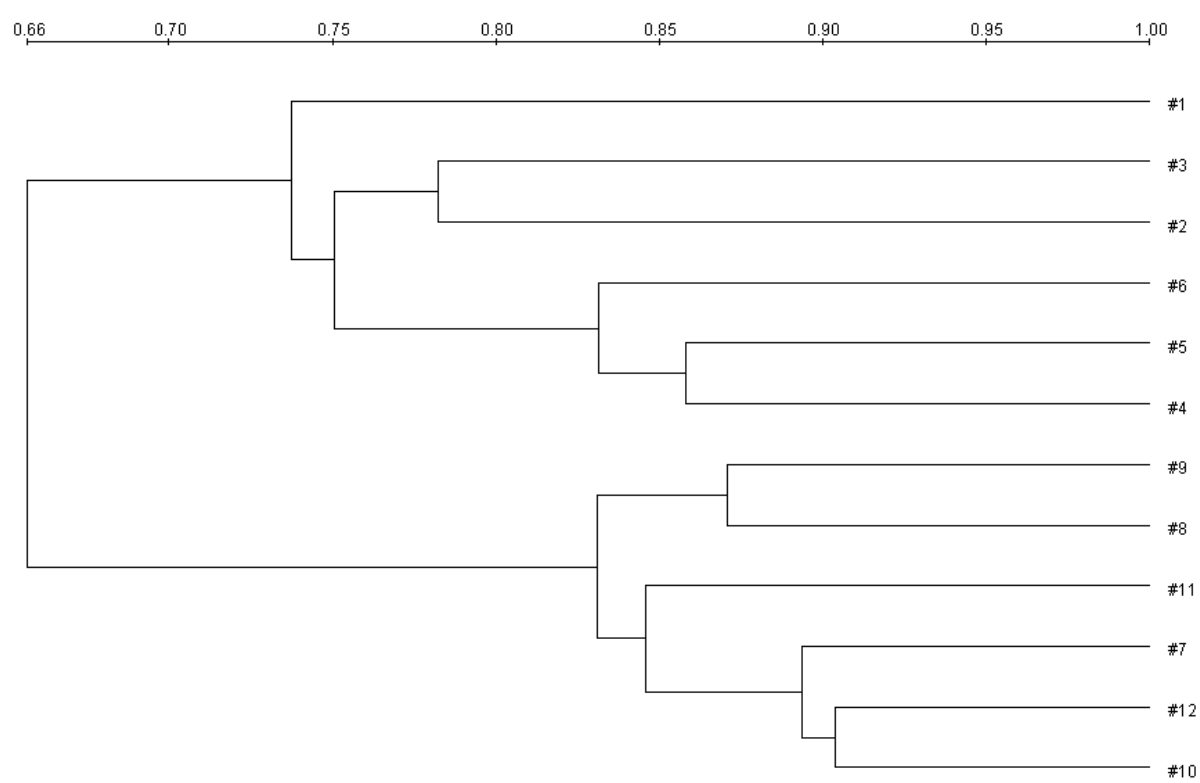

(b)

Figure 1. (a) DGGE profiles of 16S rDNA sequences amplified from DNA extracted from the eight week of the trial. Lane 1 to 6: CON; lane 7 to 12: DFM1. (b) UPGMA clustering of Figure 1(a). No. 1, 2, 3, 4, 5, 6 represent CON; No. 7, 8, 9, 10, 11, 12 represent DFM1.

al., 2000; Hong et al., 2005; Frizzo et al., 2008). Probiotics can competitively exclude pathogenic bacteria or be antagonistic towards their growth, thus helping to maintain the health of the intestinal tract (Jin et al., 1997; Hong et al., 2005). In addition, probiotics affects the bacterial population and mix as measured in the faeces (Whitley et al., 2009). An increase in the level of Bifidobacterium sp. and a decrease in Alistipes sp., Clostridium sp., Roseospira sp. was found in this study. This is consistent with changes in Bifidobacterium and Clostridium sp. reported by Guo et al. (2006), E. coli 0157:H7 reported in lamb faeces by Lema et al. (2001) and a reduction in Salmonella shedding in beef cattle reported by Stephens et al. (2007). However inconsistent results were reported by other researchers where the abundance and population density of dairy cow were improved by the addition of $B$. subtilus Pab02 (Pan et al., 2010) but no effect was found in fecal microflora after supplementing the diets of meat goats with a probiotic (Whitley et al., 2009).

\section{CONCLUSIONS}

The addition of $B$. subtilus natto to the diets of dairy cows in early lactation was shown to significantly reduce $\mathrm{NH}_{3}-\mathrm{N}$ in the faeces indicating a possible improvement in nitrogen utilization. In addition $B$. subtilus natto may change the microfloral mix within the faeces. More research is required to understand the mode of action, and the effects of these changes on animal production. 
Table 3. Percentages sequence similarity of uncultured phenotypes from fecal samples of the 8 week colonizers to other sequences in Genebank

\begin{tabular}{lllll}
\hline Bands & Treatment & Expect & Identities (\%) & Species \\
\hline 1 & Control & $9 \mathrm{e}-82$ & $170 / 171(99)$ & Uncultured bacterium \\
2 & Control & $3 \mathrm{e}-97$ & $198 / 199(99)$ & Uncultured bacterium \\
3 & DFM1 & $3 \mathrm{e}-82$ & $169 / 169(100)$ & Uncultured bacterium \\
$4-1$ & Control & $4 \mathrm{e}-91$ & $189 / 191(99)$ & Alistipes sp. \\
$4-2$ & Control & $3 \mathrm{e}-92$ & $190 / 191(99)$ & Uncultured Bacteroidales \\
$5-1$ & Control & $4 \mathrm{e}-85$ & $174 / 174(100)$ & Clostridium sp. \\
$5-2$ & Control & $2 \mathrm{e}-84$ & $173 / 173(100)$ & Uncultured bacterium \\
$6-1$ & Control & $4 \mathrm{e}-85$ & $174 / 174(100)$ & Uncultured bacterium \\
$6-2$ & Control & $9 \mathrm{e}-82$ & $170 / 171(99)$ & Roseospira sp. \\
7 & Control & $4 \mathrm{e}-85$ & $174 / 174(100)$ & Uncultured bacterium \\
8 & Control & $3 \mathrm{e}-95$ & $195 / 196(99)$ & Uncultured beta proteobacterium \\
9 & DFM1 & $1 \mathrm{e}-96$ & $197 / 198(99)$ & Uncultured bacterium \\
$9-1$ & DFM1 & $2 \mathrm{e}-83$ & $171 / 171(100)$ & Uncultured bacterium \\
$9-2$ & DFM1 & $2 \mathrm{e}-83$ & $171 / 171(100)$ & Clostridium sp. \\
$10-1$ & DFM1 & $8 \mathrm{e}-93$ & $188 / 188(100)$ & Bifidobacterium \\
$10-2$ & DFM1 & $6 \mathrm{e}-99$ & $199 / 199(100)$ & Uncultured bacterium \\
11 & DFM1 & $9 \mathrm{e}-82$ & $170 / 171(99)$ & Uncultured bacterium \\
\hline
\end{tabular}

\section{ACKNOWLEDGMENTS}

The investigation was financially supported by National Basic Research Program (973) of China (2011CB100805) and grants (No.2012BAD12B02-5 and No. 2004DA125184G1103) from Ministry of Science and Technology.

\section{REFERENCES}

Abe, F., N. Ishibashi, and S. Shimamura. 1995. Effect of administration of Bifidobacteria and lactic acid bacteria to newborn calves and piglets. J. Dairy Sci. 78:2838-2846.

Berg, E. L., C. J. Fu, J. H. Porter, and M. S. Kerley. 2005. Fructooligosaccharide supplementation on the yearling horse: Effects on fecal $\mathrm{pH}$, microbial content and volatile fatty acid concentrations. J. Anim. Sci. 83:1549-1553.

Bromner, J. M. and D. R. Keeney. 1965. Steam distillation methods of determination of ammonium, nitrate and nitrite. Anal. Chem. Acta. 32:485-495.

Campbell, J. M., G. C. Fahey, and B. W. Wolf. 1997. Selected indigestible oligosaccharides affect large bowel mass, cecal and fecal short-chain fatty acids, $\mathrm{pH}$ and microflora in rats. $\mathrm{J}$. Nutr. 127:130-136.

Cole, N. A., R. N. Clark, R. W. Todd, C. R. Richardson, A. Gueye, L. W. Greene, and K. McBride. 2005. Influence of dietary crude protein concentration and source on potential ammonia emissions from beef cattle manure. J. Anim. Sci. 83:722-731.

de Boer, I. J. M., M. C. J. Smits, H. Mollenhorst, G. van Duinkerken, and G. J. Monteny. 2002. Prediction of ammonia emission from dairy barns using feed characteristics Part 1: Relation between feed characteristics and urinary urea concentration. J. Dairy Sci. 85:3382-3388.

Erickson, G. E. and T. J. Klopfenstein. 2001. Managing N inputs and the effect on losses following excretion in open-dirt feedlots in Nebraska. Sci. World J. 1(S2):830-835.

FAO/WHO. 2001. Evalution of health and nutritional properties of probiotics in food including powder milk with live lactic acid bacteria. Exper consultation report: Cordoba, Argentina: Food and agriculture organization of the United Nations and World Health Orhanization.

Fox, J. T., B. E. Depenbusch, J. S. Drouillard, and T. G. Nagaraja. 2007. Dry-rolled or steam-flaked grain-based diets and fecal shedding of Escherichia coli $\mathrm{O} 157$ in feedlot cattle. J. Anim. Sci. 85:1207-1212.

Fritts, C. A., J. H. Kersey, M. A. Motl, E. C. Kroger, F. Yan, J. Si, Q. Jiang, M. M. Campos, A. L. Waldroup, and P. W. Waldroup. 2000. Bacillus subtilis C-3102 (Calsporin) improves live performance and microbiological status of broiler chickens. 2000. J. Appl. Poult. Res. 9:149-155.

Frizzo, L. S., E. Bertozzi, L. P. Soto, M. V. Zbrun, G. Sequeira, R. D. Santina, R. R. Armesto, and M. R. Rosmini. 2008. The effect of supplementation with three Lactic acid bacteria from bovine origin on growth performance and health status of young calves. J. Anim. Vet. Adv. 7:400-408.

Fromin, N., J. Hamelin, S. Tarnawski, D. Roesti, K. JourdainMiserez, N. Forestier, S. Teyssier-Cuvelle, F. Gillet, M. Aragno, and P. Rossi. 2002. Statistical analysis of denaturing gel electrophoresis (DGE) fingerprinting patterns. Environ. Microbiol. 4:634-643.

Fuller, R. 1989. Probiotics in man and animals. J. Appl. Bacteriol. 66:365-378.

Guo, X. H., D. F. Li, W. Q. Lu, X. S. Piao, and X. Chen. 2006. Screening of Bacillus strains as potential probiotics and subsequent confirmation of the in vivo effectiveness of Bacillus subtilis MA139 in pigs. Antonie van Leeuwenhoek 90:139-146.

Holzapfel, W. H., P. Haberer, R. Geisen, J. Björkroth, and U. Schillinger. 2001. Taxonomy and important features of 
probiotic microorganisms in food and nutrition. Am. J. Clin. Nutr. 73(Suppl.):365S-373S.

Hong, H. A., L. H. Duc, and S. M. Cutting. 2005. The use of bacterial spore formers as probiotics. FEMS Microbiol. Rev. 29:813-835.

Hosoi, T., A. Ametani, K. Kiuchi, and S Kaminogawa. 2000. Improved growth and viability of lactobacilli in the presence of Bacillus subtilis (natto), catalase, or subtilisin. Can. J. Microbiol. 46:892-897.

Jin, L. Z., Y. W. Ho, N. Abdullah, and S. Jalaludin. 1997. Probiotics in poultry: modes of action. Worlds Poult. Sci. J. 53: 351-368.

Krehbiel, C. R., S. R. Rust, G. Zhang, and S. E. Gilliland. 2003. Bacterial direct-fed microbials in ruminant diets: Performance response and mode of action. J. Anim. Sci. 81(E. Suppl. 2): E120-E132.

La Ragione, R. M., G. Casula, S. M. Cutting, and M. J. Woodward. 2001. Bacillus subtilis spores competitively exclude Escherichia coli O78:K80 in poultry. Vet. Microbiol. 79:133142.

Lema, M., L. Williams, and D. R. Rao. 2001. Reduction of fecal shedding of enterohemorrhagic Escherichia coli O157:H7 in lambs by feeding microbial feed supplement. Small Rumin. Res. 39:31-39.

Leser, T. D. and L. Mølbak. 2009. Better living through microbial action: the benefits of the mammalian gastrointestinal microbiota on the host. Environ. Microbiol. 11:2194-2206.

Maruta, K., H. Miyazaki, Y. Tadano, S. Masuda, A. Suzuki, H. Takahashi, and M. Takahashi. 1996. Effects of Bacillus subtilis C-3102 intake on fecal flora of sows and on diarrhea and mortality rate of their piglets. Anim. Sci. Technol. 67:403-409.

Medina, B., I. D. Girard, E. Jacotot, and V. Julliand. 2002. Effect of preparation of Saccharomyces cerevisiae on microbial profiles and fermentation patterns in the large intestine of horses fed a high fiber or high starch diet. J. Anim. Sci. 80:2600-2609.

Meyer, P. M., A. Vaz Pires, A. R. Vagadlo, J. M. Correia de Simas, and I. Susin. 2001. Adição de probiótico ao leite integral ou sucedáneo e desempenho de bezerros da raça holandesa. Scientia Agricola 58:215-221.

Miettinen, M., J. Vuopio-Varkila, and K. Varkila. 1996. Production of human tumor necrosis factor alpha, interleukin-6, and interleu-kin-10 is induced by lactic acid bacteria. Infect. Immun. 64:5403-5405.

Mohammed, N., N. Ajisaka, Z. A. Lila, K. Hara, K. Mikuni, K. Hara, S. Kanda, and H. Itabashi. 2004. Effect of Japanese horseradish oil on methane production and ruminal fermentation in vitro and in steers. J. Anim. Sci. 82:1839-1846.

Muyzer, G., A. Teske, C. O. Wirsen, and H. W. Jannasch. 1995. Phylogenetic relationships of Thiomicrospira species and their identification in deep-sea hydrothermal vent samples by denaturing gradient gel electrophoresis of $16 \mathrm{~S}$ rDNA fragments. Arch Microbiol. 164:165-172.

Ozawa, K., H. Yokota, M. Kimura, and T. Mitsuoka. 1981. Effects of administration of Bacillus subtilis strain $\mathrm{BN}$ on intestinal flora of weanling piglets. Nippon Juigaku Zasshi 43:771-775.

Qiao, G. H., A. S. Shan, N. Ma, Q. Q. Ma, and Z. W. Sun. 2010. Effect of supplemental Bacillus cultures on rumen fermentation and milk yield in Chinese Holstein cows. J. Anim. Physiol. Anim. Nutr. 94:429-436.

Qin, Z. H., J. P. Cai, and X. H. Ye. 2005. Cloning and phylogenetic analysis of $16 \mathrm{~S}$ rRNA gene of Bacillus subtilis natto. Chinese J. Microecol. 17:324-326.

Santoso,U., K Tanaka, and S. Ohtani. 1995. Effect of dried Bacillus subtilis culture on growth, body composition and hepatic lipogenic enzyme activity in female broiler chicks. Br. J. Nutr. 74:523-529.

Santoso,U., S. Ohtani, K. Tanaka, and M. Sakaida. 1999. Dried Bacillus subtilis culture reduced ammonia gas release in poultry house. Asian-Aus. J. Anim. Sci. 12:806-809.

Scot, E. D., T. R Callaway, R. D Wolcott, S.Yan, M. Trevor, G. H. Robert, and S. E. Thomas. 2008. Evaluation of the bacterial diversity in the feces of cattle using $16 \mathrm{~S}$ rDNA bacterial tagencoded FLX amplicon pyrosequencing (bTEFAP). BMC Microbiol. 8:125.

Spellerberg, I. F. and P. J. Fedor. 2003. A tribute to Claude Shannon (1916-2001) and a plea for more rigorous use of species richness, species diversity and the 'Shannon-Wiener' Index. Global Ecol. Biogeogr. 12:177-179.

Spiehs, M. J. and V. H. Varel. 2009. Nutrient excretion and odorant production in manure from cattle fed corn wet distillers grains with solubles. J. Anim. Sci. 87:2977-2984.

Stefan J. Green. 2005. A guide to denaturing gradient gel electrophoresis. Version 1-Nov 21.

Stephens, T. P., G. H. Longeragan, E. Karunasena, and M. M. Brashears. 2007. Reduction of Escherichia coli $\mathrm{O} 157$ and Salmonella in feces and on hides of feedlot cattle using various doses of a direct-fed microbial. J. Food Prot. 70:2386-2391.

Sumi, H. 1997. Antibacterial activity of Bacillus natto-growth inhibition against Eschricchia coli O-157. Biosci. 14:47-50.

Sun, P., J. Q. Wang, and H. T. Zhang. 2010. Effects of Bacillus subtilis natto on performance and immune function of preweaning calves. J. Dairy Sci. 93:5851-5855

Swyers, K. L., A. O. Burk, T. G. Hartsock, E. M. Ungerfeld, and J. L. Shelton. 2008. Effects of direct-fed microbial supplementation on digestibility and fermentation endproducts in horses fed low- and high-starch concentrates. J. Anim. Sci. 86:2596-2608.

Tannock, G. W. 2001. Molecular assessment of intestinal microflora. Am. J. Clin. Nutr. 73:410-414.

Teo, A.Y. L. and H. M. Tan. 2005. Inhibition of Clostridium perfringens by a novel strain of Bacillus subtilis isolated from the gastrointestinal tracts of healthy chickens. Appl. Environ. Microbiol. 71:4185-4190.

Teo, A.Y. L. and H. M. Tan. 2006. Effect of Bacillus subtilis PB6 (CloSTAT)on broilers infected with a pathogenic strain of Escherichia coli. J. Appl. Poult. Res. 15:229-235.

Timmerman, H. M., L. Mulder, H. Everts, D. C. van Espen, E. van der Wal, G. Klaassen, S. M. G. Rouwers, R. Hartemink, F. M. Rombouts, and A. C. Beynen. 2005. Health and growth of veal calves fed milk replacers with or without probiotics. J. Dairy Sci. 88:2154-2165.

Walter, J., N. C. Heng, W. P. Hammes, D. M. Loach, G. W. Tannock, and C. Hertel. 2003. Identification of Lactobacillus reuteri genes specifically induced in the mouse gastrointestinal tract. Appl. Environ. Microbiol. 69:2044-2051. 
Wehnes, C. A., K. N. Novak, V. Patskevich, D. R. Shields, J. A. Whitley, N. C., D. Cazac, B. J. Rude, D. Jackson-O’Brien, and S. Coalson, Smith, M. E. Davis, and T. G. Rehberger. 2009. Benefits of supplementation of an electrolyte scour treatment Parveen. 2009. Use of a commercial probiotic supplement in meat goats. J. Anim. Sci. 87:723-728.

with a Bacillus-based direct-fed microbial for calves. Probiotics Antimicrob. Proteins 1:36-44.

Yu, Z. T. and M. Mark. 2004. Comparisons of different hypervariable regions of rrs genes for Use in fingerprinting of microbial communities by PCR-denaturing gradient gel electrophoresis. Appl. Environ. Microbiol. 70:4800-4806. 